\title{
Art-Machines, Body-Ovens and Map-Recipes: Entries for a Psychogeographic Dictionary
}

\author{
kanarinka \\ The Institute for Infinitely Small Things \\ kanarinka@ikatun.com
}

A map is more than a picture, but what are artists doing about it? "Mapping" has exploded as an artistic practice. Artists are making geographic maps, psychogeographic maps, sound maps, demographic maps, data-driven maps, and emotional maps. Artists are performing maps-enacting and documenting location like never before. With the advent of new media art, GIS and mobile technologies, the concern with data collection and mapping through locative media is pursued with both romance and criticality. This article presents a dictionary of terms and projects that demonstrate the variety and complexity of these map-art practices. These projects utilize the map in a political and social dimension to produce new configurations of space, subjectivity and power. Their methodology is based on an ethics of experimentation; the map is a tool to experiment with a particular territory in specific ways in order to reach unforeseen destinations.

Keywords: psychogeography, art, technology, political mapping, social mapping, public space, urbanism, performance, counter-authorship, cooking

\section{INTRODUCTION}

The diagram is no longer an auditory or visual archive but a map, a cartography that is coextensive with the whole social field. It is an abstract machine. It is a machine that is almost blind and mute, even though it makes others see and speak.

Deleuze (1988)

"Cartography" refers to the choice of new worlds, new societies. Here, the practice of the cartographer is immediately political.

Rolnik (1998) 【et's get it all on the table: I'm no cartographer and $\perp$ this essay can't tell you what cartography is, or where it has been, or where it's going.

What I can tell you is that practices near cartography, often involving cartography, have exploded as an artistic practice. Artists are making geographic maps, psychogeographic maps, demographic maps, datadriven maps, emotional maps. Artists are performing maps-enacting and documenting location like never before. With the advent of new media art and mobile technologies, the concern with data collection and mapping through locative media is pursued with both romance and criticality. What I've attempted here is a dictionary of terms and projects that demonstrate the variety and complexity of these map-art practices.

As an artist, what I have seen in the past few years is an exciting convergence of artistic and cartographic practices under the term "psychogeography" (see Psychogeography). The interesting thing is that the practices that are emerging might be unrecognizable to professionals in either field. The projects I describe might not qualify as cartography and they might also not be art. Where then are these projects located? Perhaps the are located in a third space (or fourth, fifth, or nth space that has yet to be given a name). What is certain is that all of the projects have an interest in the articulation of space, in social and political engagement, and in geographies of various kinds. Whether the projects qualify as art or as cartography is not necessarily the most interesting question. What's more important is the kind of agency that these projects propose: in other words, what do these projects do?

\section{What is a Map? It's Not a Picture}

Like making a painting, making a map is traditionally associated with representation and the "totalizing 
eye"; the desire to see, know, and grasp the world in its totality. As DeCerteau (1984) acknowledges in his book, The Practice of Everyday Life:

The desire to see the city preceded the means of satisfying it. Medieval or Renaissance painters represented the city as seen in a perspective that no eye had yet enjoyed. This fiction already made the medieval spectator into a celestial eye. It created gods. The totalizing eye imagined by the painters of earlier times lives on in our achievements. The same scopic drive haunts users of architectural productions by materializing today the utopia that yesterday was only painted. [...] The panorama-city is a "theoretical" (that is, visual) simulacrum, in short a picture, whose condition of possibility is an oblivion and a misunderstanding of practices (92).

Mapping in this traditional sense is associated with spatial, pictographic practices, that is to say, with the creation of a representation of the world. A map is a picture of reality - a representation of the earth's surface; a real, neutral, objective representation, just like a photograph. A picture of an apple describes an apple. Right? Wrong. Beep. Sorry.

Any representation of the world that asserts its neutrality and objectivity is immediately suspect. Representations, pictures, descriptions must be considered in the light of their production and the politics of power. Whose apple? Whose map? Whose city? Making art, like making maps, is about making a selection from the complexity of the world, choosing to highlight certain things while others go unnoticed. As Deleuze puts it at one point, "many cities and always another city in the city" (Rajchman, 2000: 74). So many perspectives, so many people, so many politics. This can often leave an artist (and a cartographer, I imagine) in a perspectival quandary - how does one do anything at all?

Compounding the problem is the accelerated pace at which the world now operates. If the information revolution and the knowledge economies of the past half-century have taught us anything, it is that the dimension of time is of utmost consideration. Fixed representations rapidly decay into unusability and anachronism. As the rates of information transfer and physical production accelerate, the picture cannot keep up. The workings of this complex world of informational capitalism, a term coined by Castells (2000), have conspired against the inert picture:

What characterizes the current technological revolution is not the centrality of knowledge and information, but the application of such knowledge and information to knowledge generation and information processing/communication devices, in a cumulative feedback loop between innovation and the uses of innovation (16).

Cartographers used to make maps. Artists used to make pictures. What do we do now? Do we now need to make pictures that incorporate time? Do we make pictures that incorporate time and assert our own politically fallible, class/race/culture-based subjective perspective?

That sounds way too complicated.

\section{It's Not About Making a Better Picture}

The question now for artists (and likely for cartographers) is emphatically not how to make a "better" picture or a more "accurate" map. The world, in fact, needs no representations at all. It needs new relations and new uses: in other words, it needs new events, inventions, actions, activities, experiments, interventions, infiltrations, ceremonies, situations, episodes and catastrophes. We have departed from a world of forms and objects and entered a world of relations and events. But we still desperately need art and maps.

Is it possible to think of a map not as a representation of reality but as a tool to produce reality?

\section{Maps: Recipes for the Future}

As Deleuze (1988) says, a map is "an abstract machine. It is a machine that is almost blind and mute, even though it makes others see and speak" (34). The map is a machine oriented towards experimentation with the real. It is "abstract" because the map in no way represents what is already actual and determined, but instead offers a field of potential space, an array of potential uses of the actual. It is a "machine" because of its ability to bring heterogeneous elements of a system into connection with one another.

The map is software in this sense. It is intimately associated with the performances that make use of it, something like a cooking recipe. A recipe is an abstract set of instructions designed for concrete use. Recipes can be more and less specific (a dash of this or that), but are never fully determined without being enacted and performed.

Who or what performs a recipe to make a turkey, for example? A combination of bodies and machines (the chef/s, the knives, the oven), and you could never mistake a recipe-usually a set of instructions on paper-for the turkey that it produces. The recipe doesn't depict the turkey, describe the turkey, or say anything at all about any turkey it's ever produced. A recipe is a machine that produces a turkey when combined with certain concrete agents, bodies and situations (the chef, the turkey, the oven, the holiday). Recipes don't just produce turkeys - they can produce cookies, good cheer, changes in blood sugar, social mishaps, and so on.

The recipe includes its baking performances and social outcomes in a "virtual" space (which is distinct 
from cyberspace's "virtual") that stretches out into a quasi-infinity of potential uses. There are so many different turkeys that one could bake, so many holidays to have. Like a recipe, a map needs to be activated and used-supplied with particular agents, goals, ingredients, data and other specifics - in order to do anything useful. And, as with most software, performance (not representation) is the issue that is really at stake.

\section{Some Disclaimers and Caveats}

This is not a comprehensive survey of map art practices. As I am primarily a practitioner, these are some examples that I have come across in the past two years through direct experience, contact and/or participation. I also discuss a number of projects that I have been involved with as an artist and that form part of my own artistic practice. Though different projects are discussed in relationship to particular entries (complexity or psychogeography), many of the projects could fit equally well into other categories. These terms are, in a sense, a set of common interests and strategies for the artists discussed here.

Finally, the practices and projects included in this dictionary make absolutely no claim to originality. The artists have probably stolen, hacked, and appropriated most of their ideas. Historically speaking, these projects have borrowed from and been informed by diverse sources from street theater to complexity theory. As specific art practices, influences such as the Futurists, Dada, Fluxus, and the Situationist International are apparent. However, tracing these influences is outside of the scope of this small, incomplete dictionary of the present. What follows are concepts and projects important to artists working in, with, near, around and through maps.

\section{The Incomplete Dictionary of Key Concepts in Contemporary Psychogeography}

Complexity: The degree to which the structure and behavior of a system is difficult to understand due to its intricacy, size, number of relationships between components, and mutations/interactions over time.

A situation of complexity necessitates the use of a strategy that is very different from the panoramic eye of representation and picture-making, for how can one represent something that (1) is constantly evolving in unpredictable ways and (2) is never, at any point in time, fully determined. Rather than describing such systems in deterministic ways (for example, painting a picture of the system), complexity theorists speak of patterns of behavior-recurrent behavior, typical behavior, spheres of attraction, phase transitions, bifurcations-that unfold over time.
So what constitutes a complex system? The thing is, everything is complex! When you shift perspective, change your scale of investigation (see Scale), things that we think of as simple building blocks are revealed to be parts of large, cooperative systems and contain within them complex systems of their own. At different scales, we homogenize some things in order to see other things.

Along with an ethics of experimentation, many artists are forming a commitment to the excavation of complexity - to pointing out just how much difference, singularity and particularity lurks beneath a homogenized surface. For example, Sifting the Inner Belt (2004-2005) is a year-long "social research and performance project" that takes as its starting point a small, community garden in Boston's South End neighborhood. For one year, Hiroko Kikuchi, Jeremy Liu, and a collaborative team of artists, community activists and residents (myself included) investigated the Berkeley Street Community Garden and its relationship to the changing landscape of the South End, a diverse neighborhood bordering Chinatown, which is witnessing increasing gentrification. Using a variety of techniques from ecology to ethnography (see Transdisciplinary), the project seeks to document and create relationships between the gardeners, residents, and visitors and use performance art as a methodology to conduct social research.

Among the sub-projects of this initiative, each month we conduct a "Bridging Performance," an activity designed to create a "bridge" (linguistic, performative, metaphorical) between the garden itself and the Boston Center for the Arts, a large art complex across the street. These two spaces, though physically positioned only a few hundred feet apart, have vastly different audiences and constituencies. A destination relevant to one community (like a community garden) might have gone entirely unnoticed by another.

During the Bridging Performance on June 3rd, 2005, the project used a photocopied map of the South End neighborhood in a survey about zoning. The U.S. Department of Housing and Urban Development (HUD) designated Boston an "Empowerment Zone" in January 1999. This designation carried an award of over ten million dollars dedicated to generating "economic selfsufficiency for individuals, families, and communities through job creation and human development" (U.S. Department of Housing and Urban Development, 1999). Ten million dollars is a lot of money to get just because HUD declares you an empowerment zone. Interested in the power of language to shape funding and strategic urban development in relationship to zones of the city, the project created a small-scale, informal survey about "Empowerment Zones". Pairs of researchers were deployed to different strategic locations in the South End. These included our main 
geographic foci of the Berkeley Street Community Garden and Boston Center for the Arts, but also included areas at the high and low end of the economic spectrum of the neighborhood, including the SOWA Arts Complex, the Castle Square projects, and the Villa Victoria projects. We stopped people in public spaces and asked each person to identify their empowerment zone on a photocopied map of the neighborhood [see Figure 1].

The responses were diverse. A police officer in the projects circled the areas that South End gangs fight over. Many visitors to the galleries in the SOWA Arts Complex, often not residents of the neighborhood, circled the Boston Center for the Arts and the commercial district on Tremont Street. An AfricanAmerican woman hanging out with several men on a street corner next to the SOWA Arts Complex named the Division 4 police station as her zone of empowerment, stating, "I own them." A middle-aged Caucasian woman, looking uncomfortable, stated that she felt most comfortable in Cape Cod so she circled the highway that led to it. A movie buff, not a resident of the neighborhood, circled the video stores that he travels miles to rent from. A middle-aged Caucasian man circled all the places where he and his wife owned property. A Caucasian woman traced her walking route through the neighborhood. A young Latino man circled his cousin's house. A suburban wife stated that her zone of empowerment was her husband's wallet. One wealthy couple complained vehemently about the lack of parking in the area. When asked to participate, a man carrying a beer in a brown paper bag stated that he was too drunk.

Using one map, we collected a different story and a different empowerment zone for every person that we surveyed. There was a distance between many of these

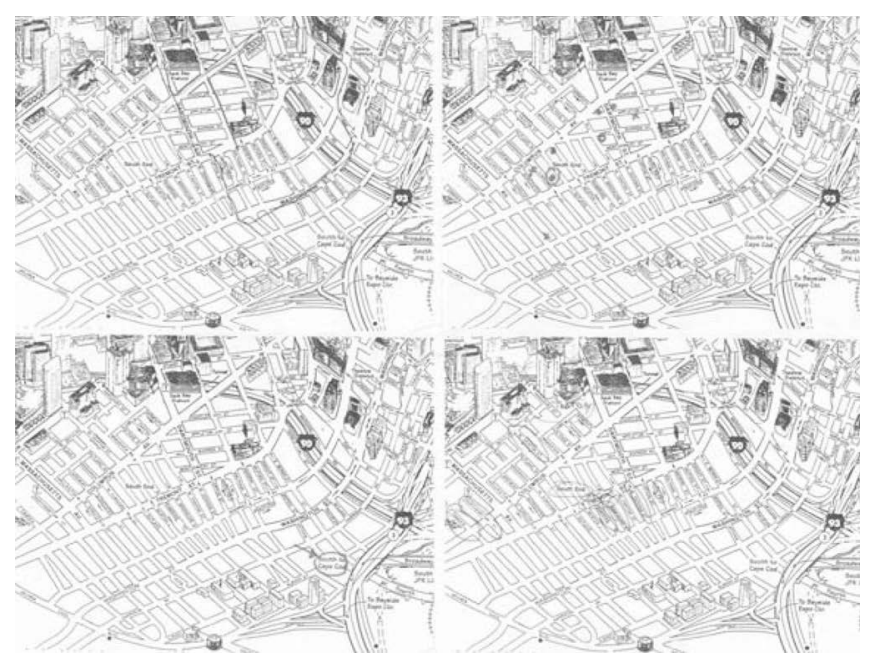

Figure 1. Residents of Boston's South End were asked to circle their "Empowerment Zone" for the project Sifting the Inner Belt (2004-5). (see page 76 for color version) people (and between us, the researchers) that belied our geographic proximity. On the map, we were all more or less in the same place, but it is clear from the survey that the people we stopped inhabited distinct worlds.

As a mapping exercise, this performance and the larger Sifting the Inner Belt project serve to highlight the social, political and economic limitations of any purely geographical measurements of proximity - How close are the gardeners to the Boston Center for the Arts? How close are the art patrons to Chinatown or to the projects? The project seeks not to visually map these measurements and relationships, but to map them in an embodied, performative, particular manner: to actively engage with the diverse communities that surround the Berkeley Street Community Garden and to create awareness of the difference and heterogeneity that exists in a small geographical space.

Related Terms: Data Collection, Scale, Transdisciplinary

Related URLS: Sifting the Inner Belt (www.siftingtheinnerbelt.com)

Collaboration and Cooperation: Work done together for a common purpose.

Note that collaboration and cooperation may be with other people, an institution, a landscape, even an hour of the day. Groups of artists have always worked collectively, but recently it has been increasingly important to explicitly label these practices as collective versus individual. Art collectives are often composed of semi-anonymous, often temporary or fluctuating members such as Glowlab, iKatun. If members of the group are anonymous, there might be political reasons for concealment of identity (for example The Institute for Applied Autonomy), or specific philosophical experimentation with agency and the production of subjectivity (for instance, spurse). Sometimes what is presented as an art collective is actually an individual acting as a collective of one, such as Swoon or The Atlas Group. There are almost as many models for collaboration as there are art collectives (see list below).

The rise in explicit acknowledgement of collaborative practices points to an important shift in how we are imagining agency in the world. The individual used to be the primary site of agency: the artist used to be a tormented, brilliant genius. Probably he was a guy and lived in a dusty garret/penthouse/loft in fashionably bad neighborhood. Perhaps he threw paint around in fits of anger/sadness/other expressive emotions. Think of stereotypes like Jackson Pollock or Hollywood tropes like the movie Shakespeare in Love.

Though it still sells well, there are clear limitations to imagining agency as purely individual. First of all, 
the rise in transdisciplinary practices and new technologies means that it is increasingly difficult for one person to master all the tools she needs to make interesting work (see Transdisciplinary). The very idea of "mastery", in a technical sense, is not what is at stake in art-making anymore. Operating as a loose collective can support shifting members, fluid skills, varying degrees of expertise and engagement. Also, very simply stated, collectives get more accomplished.

Most importantly, the collective can be thought of as an explicit act of cultural resistance in that the group functions as a refusal of an increasingly engineered individual subjectivity. In a political economy of global capitalism, it is directly in the interest of the communications industries to produce individual subjectivity, that is to say, to cultivate, nurture, and feed the myths of the individual. In the current advertising climate, it's all about me, what I want, how I feel, what I might need to consume in order to feel better about me. From the images to the slogans- "Find Your Own Road," "Make It Yours," "Accelerate Your Life," "Celebrate the moments of your life," "Grab life by the horns," "Thousands of possibilities. Get Yours," - the production of me as a daring, passionate individual and consumer is incessant.

Displacing agency to the collective is a structure that works to neutralize that communications machine. Working collectively is a way to work around and outside the production of the individual. Reimagining our agency as collective opens up new possibilities for social and political action that are unthinkable if we can only imagine agency situated at the level of the individual human being.

So what does agency have to do with artistic practices of mapping? A lot. Beginning to think about maps as recipes (instructions for use) means that we also need to rethink the role of the mapmaker-artist. It's no longer possible for the mapmaker-artist to be a "celestial eye" that sees reality and then depicts it. This privileged panoramic view of the world is witnessing increasing dispersion, fragmentation, and displacement. The mapmaker-artist, the stable agent with a fixed identity who used to possess this view, is undergoing the same displacements and fluctuations in identity. She is becoming increasingly susceptible to difference (heterogeneity vs. homogeneity), sensitive to time, and aware of complexity at the smallest scales (see Scale). The art collective and collective action, in general are ways to creatively engage with the instability of complexity and the dispersion of agency.

Some semi-cartographic collectives: Bureau d'études, Bureau of Inverse Technology, Center for Urban Pedagogy, Critical Art Ensemble, Glowlab, iKatun, Multiplicity, N55, Nomads+Residents, spurse, subRosa, Swoon, The Atlas Group, The Bookmobile Collective,
The Institute for Applied Autonomy, The Institute for Infinitely Small Things, The Yes Men, xurban

Related Terms: Political, Scale, Transdisciplinary

Data Collection: Gathering data and collecting samples. Assembling archives. Borrowing techniques from field research in geography, ethnography, biology, and anthropology (see Transdisciplinary).

Artistically, this practice is related to the series or the multiple. Technologically, this practice can be associated with the database. A collection is, first and foremost, a heterogeneous group of related elements. As an artistic practice, it is often employed strategically, as a technique to demonstrate the variety and multiplicity of something we might gloss over as homogeneous or simple (See Complexity).

For example, the collective Glowlab is engaged in a project called One Block Radius (2004) that is collecting psychogeographic samples for the purposes of mapping a single block in New York City. Commissioned by the New Museum of Contemporary Art, the block in question spans the area from Bowery to Chrystie Street, and from Stanton Street to Rivington Street. This block is the site of a new building for the museum with construction slated to begin in 2005.

For One Block Radius, Glowlab and collaborators collect photos, video, texts, audio recordings, and interviews with residents and passersby. At the time of writing, they have collected 474 data samples. Each one is tagged with the date, the location on the block where it was collected, the name of the collector and relevant categories. Samples collected range from photos of crushed paper cups [see Figure 2] to text interviews with local business owners. Finally, each item is carefully logged on an interactive map on the project's website.

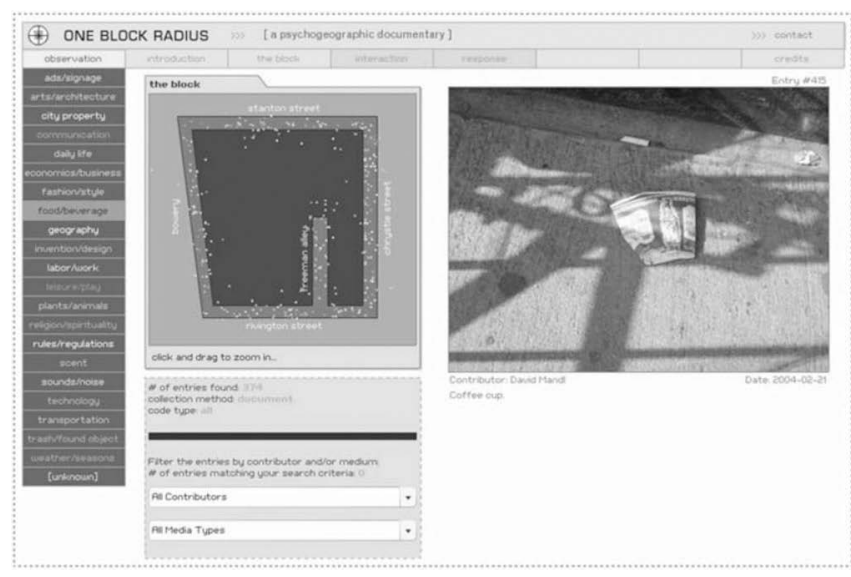

Figure 2. One Block Radius, image courtesy of Glowlab. (see page 76 for color version) 
The importance of One Block Radius is not that it creates a portrait or map of a single block, but lies, rather, in its treatment of particularity and difference. Where the "celestial eye" might neutralize the block depicting it as one in a city of blocks, Glowlab uses data collection to strategically excavate an unimaginable complexity and expose a landscape of difference and duration in a tiny geographical space.

\section{Related topics: Complexity, Transdisciplinary, Urbanism \\ Related URLS: Glowlab (www.glowlab.com); One Block Radius (www.oneblockradius.org)}

Dispersion \& distribution: Spatially - the quality being scattered over an area or volume. Temporally - the quality of being spread out over time. Artistically - A situation in which the work of art takes place in diverse physical and virtual spaces at different times.

Our artwork is becoming as asynchronous and networked as our communications. Distributed projects make use of a variety of places and times in a single project in order to reach multiple audiences, to facilitate multiple and diverse collaborations, and to produce new forms of dialogue and exchange across space and time. For example, my project Funerals for a Moment (2004) invited collaborators from around the world to submit inconsequential, ordinary moments to a website. We collected 55 such moments from people around the globe (See Data Collection). The moments presented a wide range of recollections of mundane events such as riding the subway, crossing the street, and waiting for somebody. A moment contributed by Dillon Paul, for example, occurred at 9th St. and 2nd Ave on Tuesday, December 19th, 1995 at 8:45 AM: "I ordered a bowl of borscht, again, from Veselka."

Each moment was linked to the date, time and location in New York City when it occurred and presented in an online gallery on the project's website. For the Psy.Geo.Conflux festival, I created a laminated Funeral Manual with instructions for performing a funeral for each moment submitted [see Figure 3] and then led a group of collaborators in a 2-hour processional walking ceremony where we performed funerals for eight of these ordinary, passed moments.

In terms of distribution, there were many events in different locations at different times: the original ordinary moments that occurred in New York, the individual "uploading" events in which online collaborators wrote about their moments (scattered across the globe and spaced over the 1.5 months leading up to the festival), and the performances of the funerals in public space. The actual space-time of the work was composed of all of these small, singular events.

For the project Following the Man of the Crowd

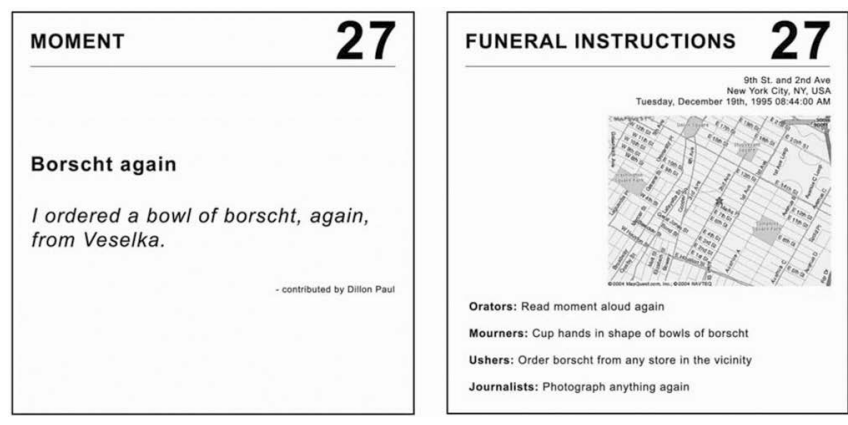

Figure 3. Funerals for a Moment guidebook, moment \#27, front and back of page. (see page 77 for color version)

(2004), the artists Christina Ray and Lee Walton did a project inspired by Vito Acconci's famous Following Piece (1969) in which he spent one month following passersby through the streets of NYC until they disappeared into a private space (see Public Space - The Commons). In Ray and Walton's piece, the artists followed people on the street and communicated via text messages on their cell phones over a period of 24 hours [see Figure 4]. While one artist followed a person in one location, the other rested in a different location. Once the person being followed had disappeared into a private space, the artist stopped, text messaged the other, and rested at that location.

Ray and Walton documented their followings with text and images on a blog site that they updated in real-time using their cell phones. Audience members "following" the project from different locations around the world could sign up to receive text updates to their cell phones whenever Ray or Walton text messaged each other or posted an entry to the blog site.

What is curious about this project is that the action and audience is, in a sense, entirely distributed. There were most likely no audience members present while Ray and Walton were actually, physically following people in the street. However, there was a large online audience that "followed" Ray and Walton through text messages and the website just as Ray and Walton followed people in physical space.

So, what is important about distribution in space and time as a mapping practice? The "celestial" view of the city (New York City, in both cases) is displaced and scattered across multiple perspectives and diverse locations. The map is situated in a temporal context and composed primarily not of visual icons but collections of particular events (viewing events, following events, remembering events, funeral events) that take place around the globe.

Related Terms: Data Collection, Public Space - The Commons, Urbanism

Related URLS: Funerals for a Moment (www.funer- 


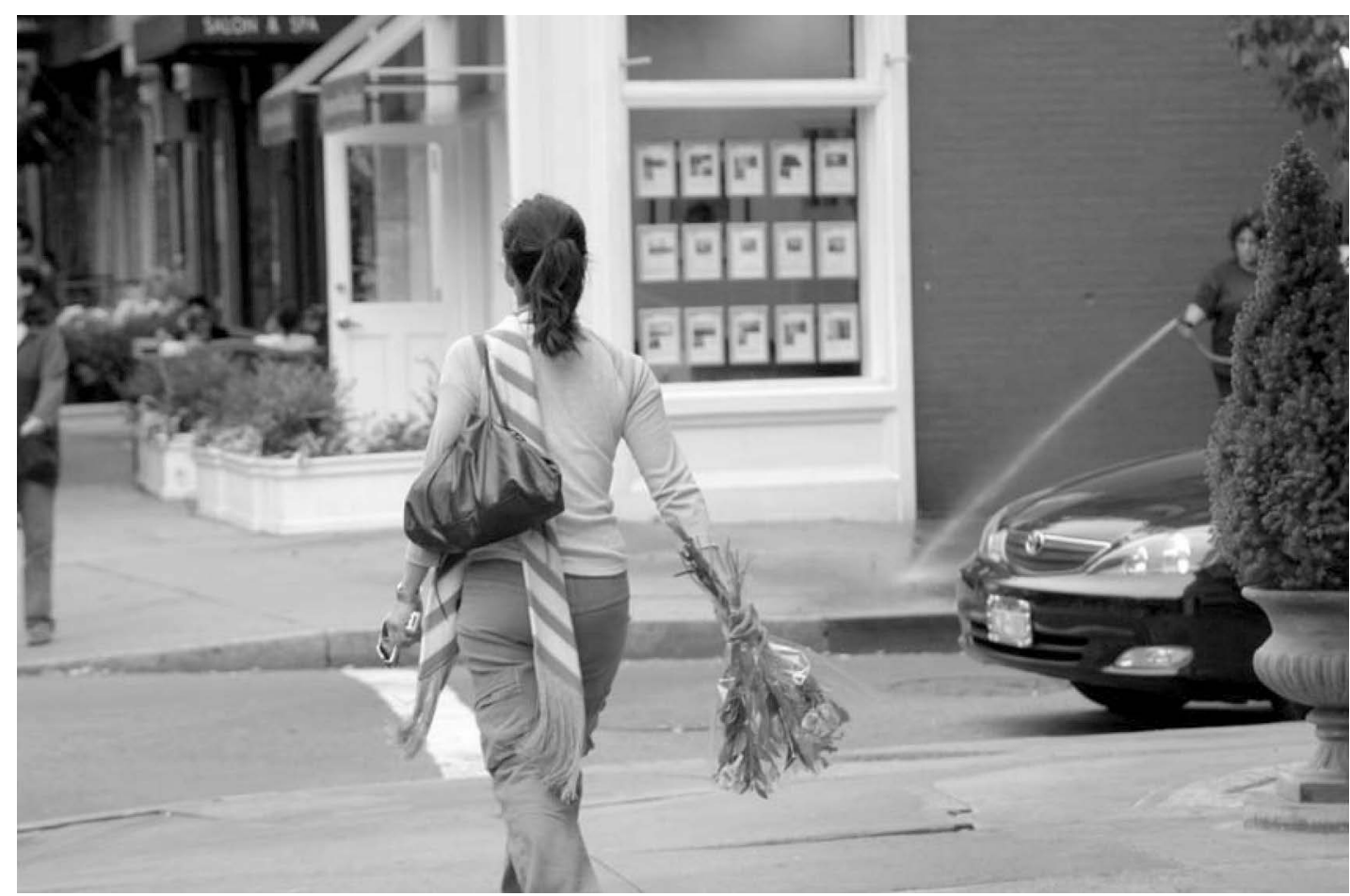

Figure 4. One of the people followed for Following the Man of the Crowd (2004) by Christina Ray and Lee Walton.

alsforamoment.net); Following the Man of the Crowd (http://glowlab.blogs.com/following/)

\section{Experiments: A controlled test or investigation into the} world.

Artistic experiments involve varying degrees of explicit mapping, structure and formality. For example, Lee Walton's piece, Making Changes (2004), splices together many short video clips of the artist "making changes" to the urban environment. These changes include actions such as moving a coffee cup from one post to another, placing bananas in the apples bin at the corner store, and turning store mannequins to face backwards. Each action is small and practically unnoticeable, but offered to the viewer to be considered as a "what if..." experiment in small, located actions.

The Italian artist, Cesare Pietroiusti, has done similar projects. In 1995, the artist was invited to do a project in the Santa Maria delle Croci church in Ravenna. On December 23, 1995, Pietroiusti opened each and every door in the seventeenth century church. This included main and secondary entrances, doors to adjacent spaces (toilets, boiler room, hallways), and doors that opened onto the street. For one day, every single door in the church stayed open [see Figure 5].

The artist Alex Villar experiments with the urban environment in similarly small, performative ways. In his project, "Dribbling the Field", he conflates the action of dribbling in a soccer game with the experience of finding one's way in the city (see Urbanism). This overlay of actions is complicated by the fact that he only "dribbles" going backwards. The video shows

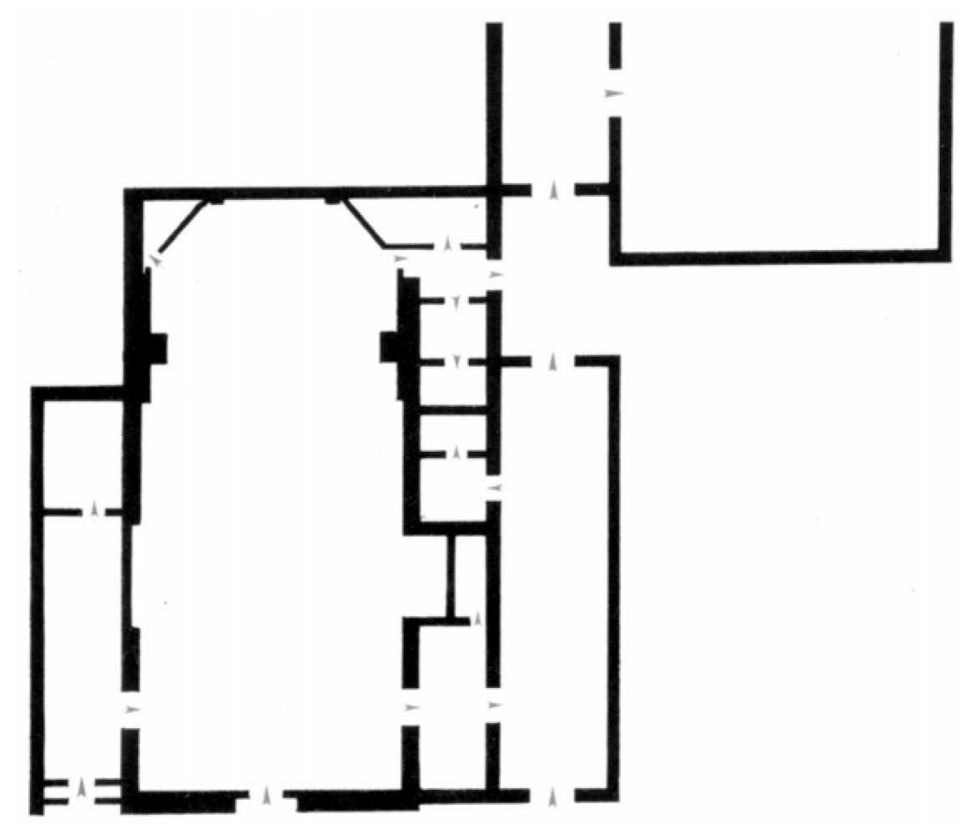

Figure 5. Architectural plan of the church Santa Maria delle Croce with all doors open, a microperformance by Cesare Pietroiusti. 
the artist "dribbling" backwards through all sorts of public spaces in New York City, provoking the curiosity and puzzlement of passersby.

A map need not be a visual artifact. These artists use tiny sets of instructions ("open all the doors in this church", "dribble backwards as if playing soccer in reverse") as the maps to guide them through experimentation with the surrounding geography. The body, in these projects, becomes the machine-the oventhat articulates space (see Performance). The body following these instructions is concrete and radically particular (the reality of the one body in one space and one time following one map) where the celestial eye is abstract and entirely generalizing (the illusion of the whole city in a picture without time). Using the body as a mapping machine and simple, abstract instructions as maps, these artists experiment with new ways of imagining the time and space of mapping practices.

Artists also experiment with new ways to use existing maps as a means of critically engaging with the process of mapmaking itself. In another piece by Walton called The Average Point Of Interest, San Francisco (2003), he took the 287 points of interest as specified on a San Francisco tourist map, averaged their coordinates, and came up with the one "average" point of interest that turned out to be on Flint Street off 15th Avenue near Corona Heights. There he installed a bronze plaque to commemorate the destination.

Using tongue-in-cheek humor, Walton makes an interesting point: who selected the 287 points of interest? Why 287? Who determines what is "interesting" about an entire city and for whom? What indirect assumptions are already included in these maps (such as assumptions about "tourism", "leisure", "historical importance") and what is not included (the radical particularity of Flint Street off 15th Avenue near Corona Heights, for example)?

Finally, experiments need not be small micro-interventions but can be sustained investigations along more traditionally scientific lines (see Transdisciplinary). The group spurse, for example, creates large-scale experiments such as boats that experiment with the coast of Maine (see Mobility) and whole institutes with research archives to investigate urbanism (see Urbanism).

Related Topics: Mobility, Performance, Transdisciplinary, Urbanism

Related URLS: Lee Walton (www.leewalton.com); Alex Villar (www.de-tour.org)

Mobility: The ability to travel freely from one place to another. In this context, leveraging mobile technologies (such as one's feet, boats, rafts, cell phones, and trucks) in order to experiment with site and context, motion and difference.

For their project Mapping the Working Coasts of Maine (2004), for example, the spurse collective designed a mobile laboratory to make a "complete" map of the working coasts. With more people moving to the coasts of Maine, coastal economies and ecosystems are undergoing major changes. Members of spurse conducted interviews with coastal workers and residents over a period of six months. These interviews culminated in a week-long journey on a boat that was converted into a laboratory, conference room and cartography studio. During public visiting hours when docked, residents from each town were invited on the boat for coffee, discussions and participation in drawing up psychogeographic diagrams of coastal relations [see Figure 6] (see Psychogeography). As a collaboration between Coastal Enterprises Inc. (a community development group), Shunpike Audio, and spurse, the project functions as a community workshop, an evolv-

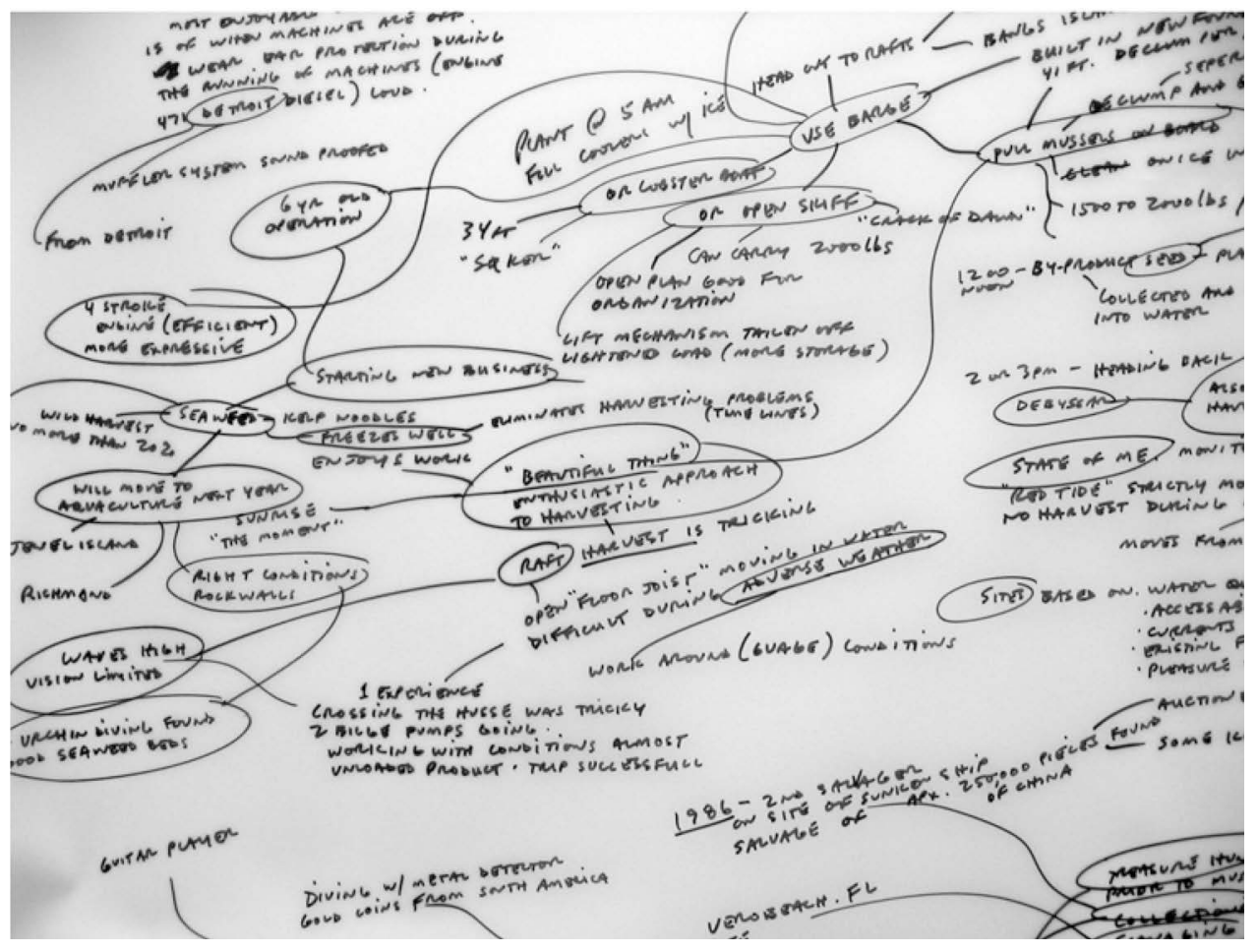

Figure 6. Mapping the Coasts of Maine, by spurse. Detail of psychogeographic diagram produced through conversations and interviews. 
ing archive, and an oral history project. All of these approaches, including, most importantly, the boat as a tool to (literally) mobilize location, are engaged as mapping technologies in this project.

As a research method, this approach is rigorously particular and experiential; more concerned with mapping differences and making connections at a sub-local level than creating general explanations or conclusions about the changing nature of the working coasts. There is, in a sense, no privileged point of view from which to view these coasts. The continuous displacement of the researchers throughout the project serves to enact this both conceptually and physically. This is not to say, however, that no results are yielded from the mobile lab. spurse conducted over one hundred interviews in the course of the project and produced as many psychogeographic maps of the working coasts. Through conversations and diagrams, spurse generated new connections, new collectives and new voices.

Other mobile projects, such as the MobilivreBookmobile (2000-2005) by the Bookmobile Collective and Traveling Magazine Table (2003-2005) by Nomads+Residents are concerned with mobility as an alternate means of information dissemination. Both traveling projects showcase collections of independent magazines, artists books and other materials that otherwise have no publisher [se Figure 7].

Mobility is also leveraged for political purposes, to assert a point about geographic displacement and the changing demographics of a city or neighborhood. Artists from the Fort Point neighborhood in Boston, including John Osorio-Buck and Matthew Ward, have

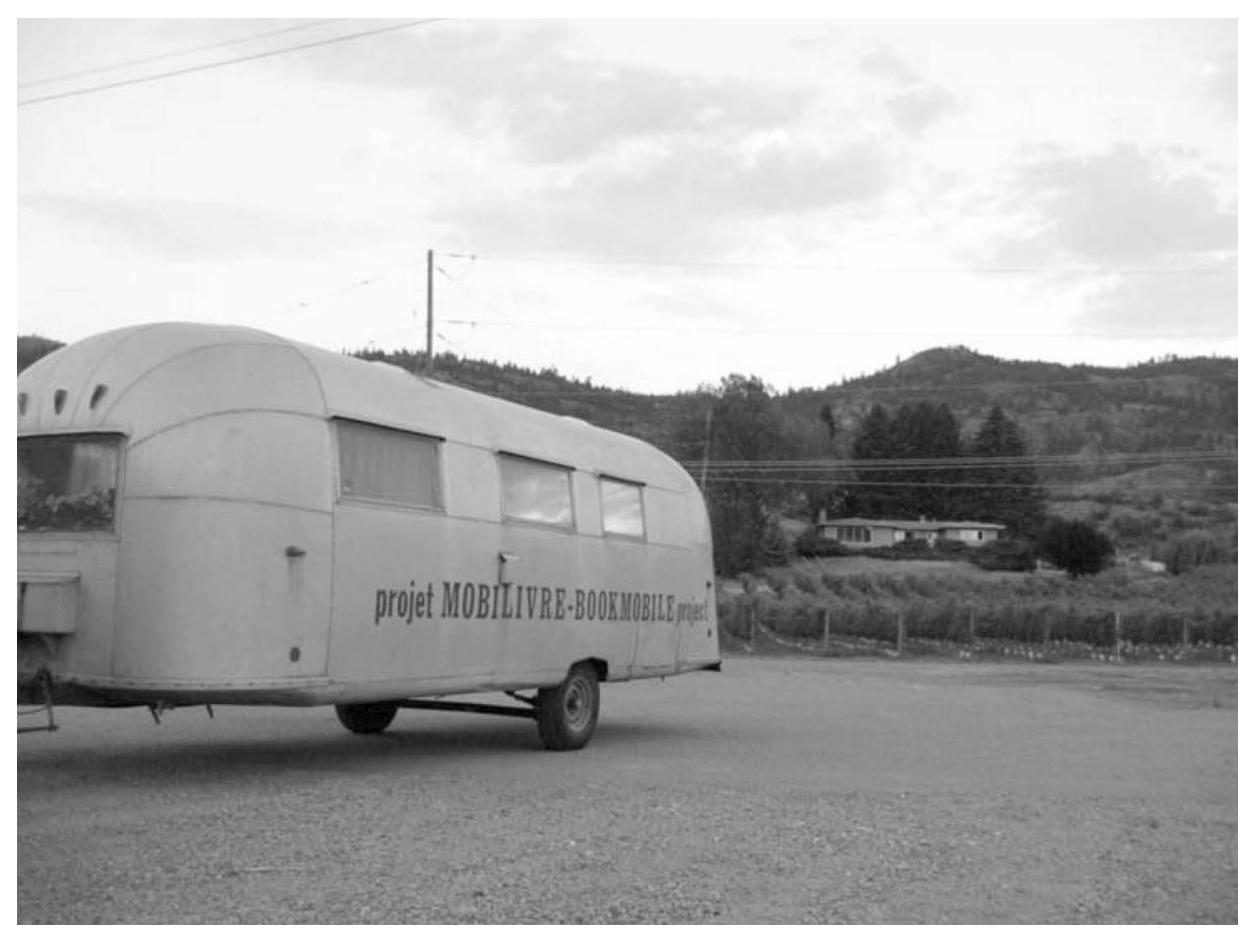

Figure 7. Bookmobile/Mobilivre project. been increasingly pushed out by the influx of businesses and professionals who can afford to purchase real estate in the area. When Osorio-Buck and Ward received news that their leases would run out, they began to design a 9-foot-by-8-foot raft that they constructed from plywood and PVC [see Figure 8]. During the fall of 2004, Osorio-Buck and Ward lived on their raft as part of the project W.T.L.F.P.A.P.T.O.T.L. (2004) which stands for "Will the last Fort Point Channel artist please turn out the lights?"

In total, the pair spent several weeks living on the raft floating up and down the Fort Point Channel, developing relationships with residents, postal workers, and construction workers in the area. The raft served to call attention to the politics of place but also functioned as the invention of a new nomadic space-temporary and shifting-near the margins of the neighborhood.

Related Terms: Collaboration, Data Collection Related URLS: Mapping the Working Coasts of Maine (www.spurse.org/mappingmainecoasts.html); projet MOBILIVRE-BOOKMOBILE (www.mobilivre. org); Nomads+Residents (www.nomadsresidents.org); W.T.L.F.P.A.P.T.O.T.L. (www.bostonraft.com) Performance: Carrying out one or multiple actions over a
period of time.

Performance, for my purposes here, is squarely located within the context of the real (as opposed to the theatrical or the imaginary). Using performance, many of these artists experiment with real life. They pose real situations with real people that are challenged to enact a real politics, a real ethics, and a real sociality in order to respond.

The Canadian artist Natalie Loveless, for example, creates durational wall drawings as maps of collaborative performances. For the project Working Notes (Participatory Democracy) (2004) at Art Interactive in Cambridge, MA, Loveless invited collaborators across the city into the gallery space for a conversation about democracy and the political process in the U.S. Each collaborator brought in objects to use as talking points. Loveless asked them to attach the objects to the wall using a variety of fixatives (from pins to tape to 

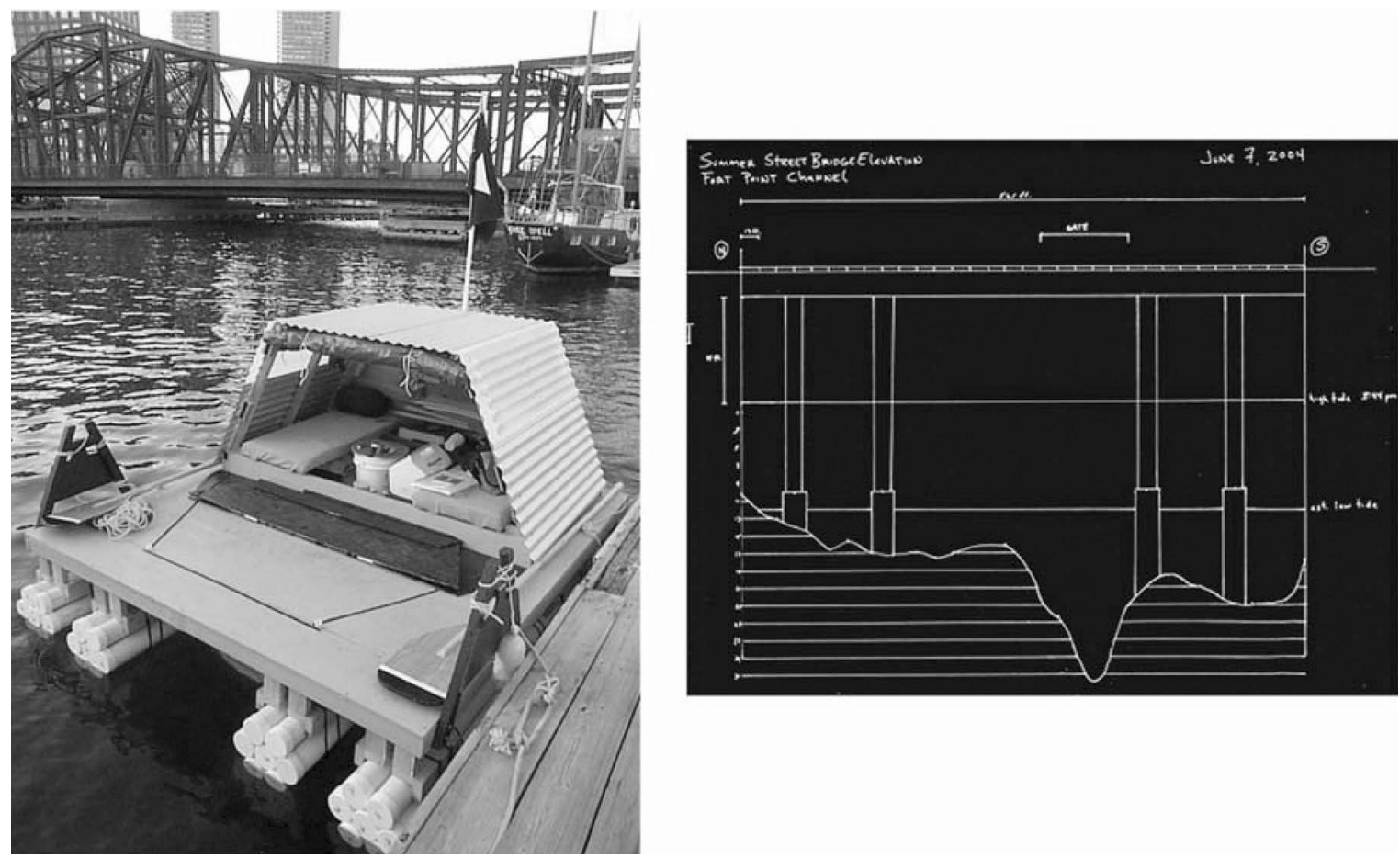

Figure 8. W.T.L.F.P.A.P.T.O.T.L. (2004) by John Osorio-Buck and Matthew Ward.

chain to glue). After the conversation, the objects were removed and, using particular rules based on connections and relationships, Loveless would map the traces that remained in silverpoint. Over the course of several months, Loveless conducted twenty-eight conversations, mapping together more than one hundred objects in a delicate, intricate drawing [see Figure 9] on the wall of the exhibition space.

Loveless' maps serve, in this case, as abstract documents of a series of conversational performances. Though they might be considered documentation of events, the maps are not pictures: they do not "represent" the conversations. It would be impossible to reconstruct the conversations that took place from looking at these maps. Loveless' wall drawings speak to a real space that is not geographical, the virtual space of perception and memory that transforms action into residue and residue into future action. Her maps live simultaneously in the past, present, and future, in and through time, the basic element of all performance.

The annual Psy.Geo.Conflux festival acknowledges and explores this intimate connection between maps and performance, action and documentation. Each year, artists, academics, and members of the public come together to investigate the field of psychogeography (see Psychogeography). All of these investigations make use of a performative engagement with geographical space. Projects at the Psy.Geo.Conflux involve absurd tours, live music performances incorporating environmental sound recordings, walking projects, and unauthorized "noise parades".

Though the projects might be variously absurdist, obscure, academic and/or carnivalesque, note that they all operate in the real. The city street and urban grid (see Urbanism), along with all of the social, economic and political relationships present there, are viewed not as the background to an imaginary story or a theatrical play but as the very substance with which one performs. For these projects, the geographical space becomes a sort of collaborator with an agency of its own.
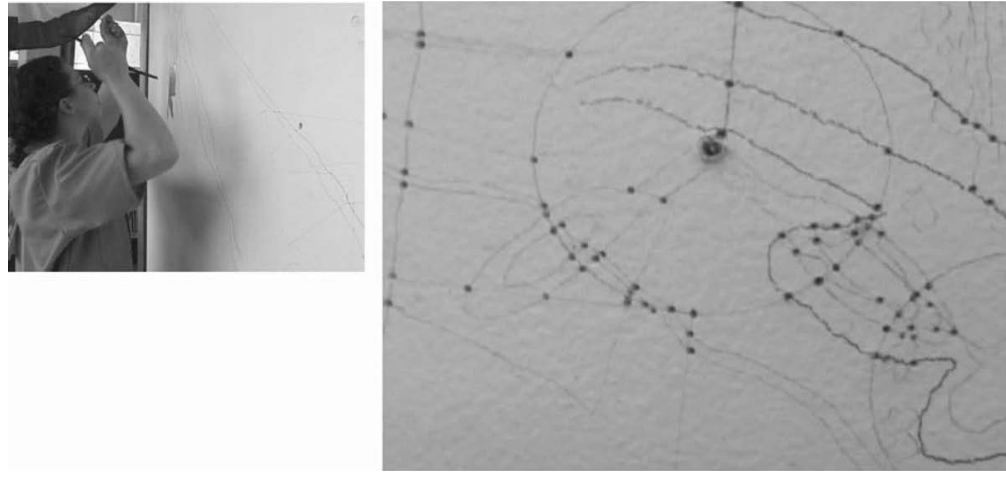

Figure 9. Participatory Democracy (2004), detail by Natalie Loveless. (see page 77 for color version) 
Related Terms: Urbanism, Psychogeography Related URLS: Natalie Loveless (www.loveless.ca); Psy.Geo.Conflux (glowlab.blogs.com/psygeocon/)

Political: Of or related to the power relationships in a given society.

The practice of mapping is immediately political, as Suely Rolnik notes in one of my epigraphs. Artistic choices are just like cartographic choices: they highlight one thing at the expense of an infinity of others. What is chosen constitutes a new world, a new life, a new society. This exercise of this power of invention is situated squarely within the realm of the political.

Some projects are more explicitly political than others. For example, the Institute for Applied Autonomy's mission is "to provide technologies which extend the autonomy of human activists" (Institute for Appliede Autonomy webpage). To this end, the Institute for Applied Autonomy released a piece of software called txtmob (2004) just before the Republican National Convention (RNC) in New York City. Activists with cell phones signed up to a text-messaging list-serve. Once they had signed up, each member could send messages to the group. The software was used during the RNC to alert protesters to police arrests at particular locations, to broadcast strategic meeting points (e.g. a message like "18:15:50 Tue., Aug 31: A31 party mtg at SE corner of Union Sq." would appear on one's cell phone), and to coordinate foot traffic (see Mobility) (Di Justo, 2004). Using txtmob, activists bypassed radio and TV reporting but still leveraged the power of a one-to-many broadcast format for the purposes of grassroots, real-time political organization in physical space.

Another project from the Institute of Applied Autonomy is i-See (2001), a web application that maps the location of surveillance cameras in lower Manhattan and plans a pedestrian route based on coordinates entered by the user in order to pass by the fewest number of surveillance cameras [see Figure 10]. iSee begins with a critique of the politics of a surveillance culture.
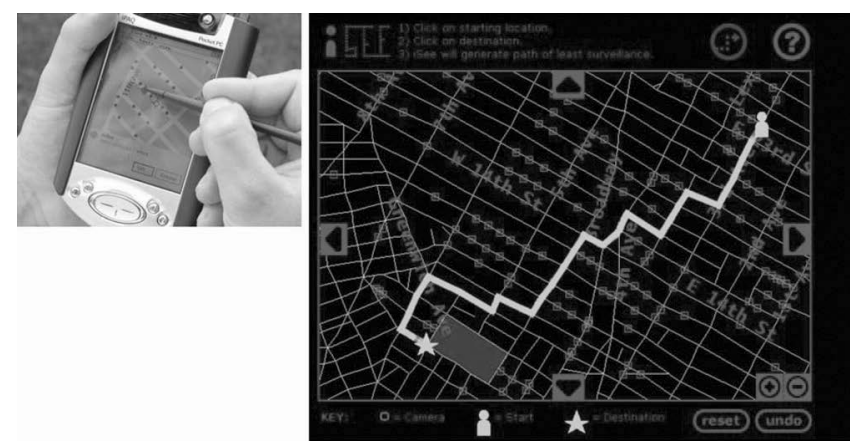

Figure 10. i-See (2001) by the Institute for Applied Autonomy maps the path where you are least likely to be watched. (see page 78 for color version)
Where does surveillance footage go? Who has access to it? What do they use it for? What is its potential for abuse? Surveillance, according to the Institute for Applied Autonomy, involves an imbalance of power and an absence of accountability and oversight. iSee, the solution they have configured, takes the user on the "path of least surveillance" in relation to this problem.

A Paris-based collective, Bureau d'études, has created the Tangential University to facilitate new research into critical cartography, capitalism, and the study of knowledge/power configurations in society. The Bureau also creates info-maps of power relationships in society with titles like Governing By Networks (2003) and infowar/psychic war (2003) [see Figure 11] that are reminiscent in intention to the artist Mark Lombardi's diagrams of influence. The maps at the Bureau d'études disclose hidden facts and relationships in order to critically examine the past and present political situation.

\section{Related Topics: Mobility, Public Space - The Com-} mons, Urbanism

Related URLS: The Institute for Applied Autonomy (www.appliedautonomy.com);

Bureau d'études \& the Tangential University (www. utangente.free.fr)

Psychogeography: The production of affect in relation to the geographical environment.

Psychogeography is a term originally coined by the Situationist International (SI), an international political and artistic movement from 1958 to 1972, which included Guy Debord, Asger Jorn, Michele Bernstein and Raoul Vaneigem. Psychogeography has previously been defined as "The study of specific effects of the geographical environment, consciously organised or not, on the emotions and behaviour of individuals" (Anon., 1958). The Situationist International (SI) sought to revolutionize art, politics and everyday life and played a major role in the 1968 student uprisings in France and across Europe. SI is often associated with the practice of the dérive, a way of walking with awareness (of one's emotions and behaviors) in urban space that breaks with habitual patterns of usage such as the commute or the stroll.

Contemporary groups and artists have appropriated this term as a nod to the influence that the SI continues to exert long after its dissolution, however contemporary practices are more diverse (due in part to the explosion of mobile technologies) and the political circumstances are radically different. Psychogeography has expanded to include not only the study of the effects of the geographical environment on the behavior and emotions of individuals, but the production of affect in relation to the geographic environment. 


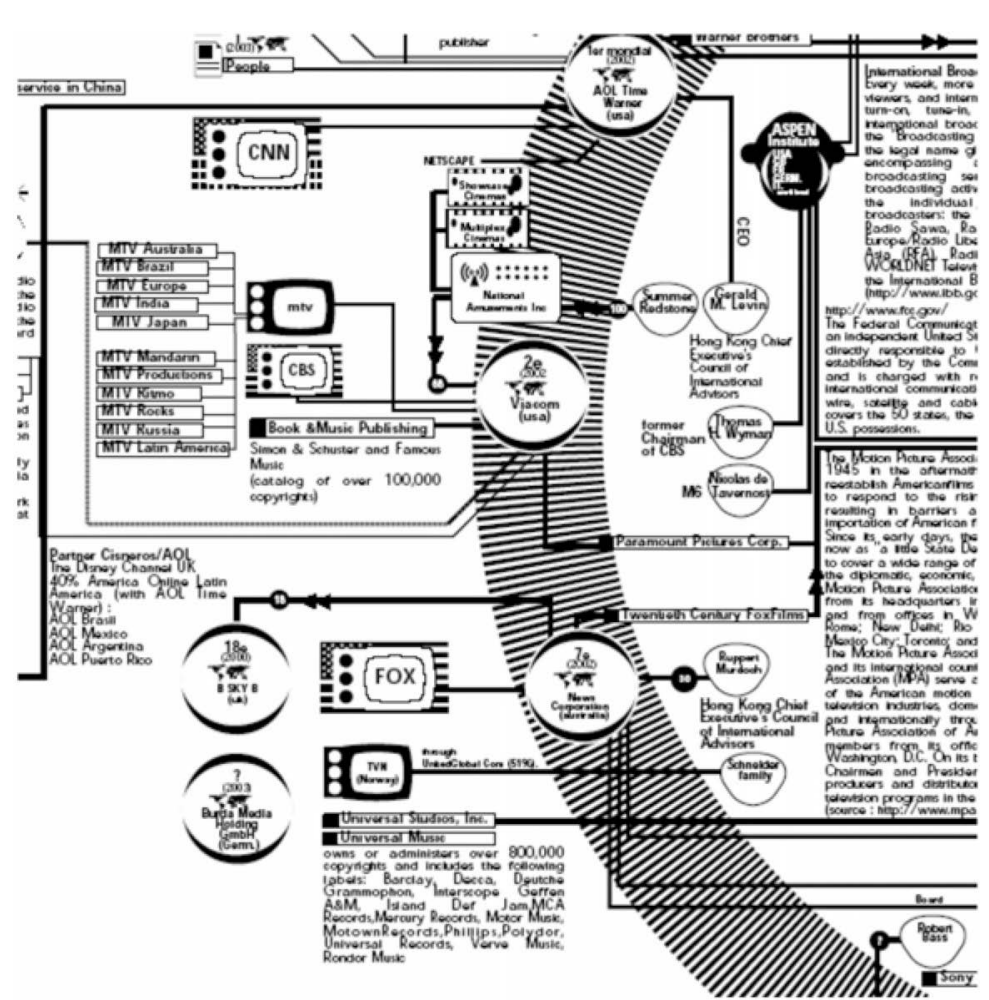

Figure 11. Infowar/psychuic war, detail by the Bureau d'Etudes. Image courtesy of the artist.

What does that mean?

This is to say that contemporary practitioners of psychogeography not only consider themselves to be investigating the "geographic environment" but to also be actively transforming that environment through the production of affect-embodied sensation as opposed to subjective emotion. And instead of focusing their social and cultural studies only on the individual, today's psychogeographic projects operate at many different spatial and temporal scales-the individual, the community garden, the street corner, the sidewalk, the RNC, the artist community, the floor of the Fort Point Channel in the Fall, and so on. Each of these spatial and temporal contexts becomes an arena in which to conduct a psychogeographic investigation.

All of the projects in this dictionary (plus many others not discussed here) fall into the category of psychogeography.

Related URLS: Glowlab (www.glowlab.com); Providence Initiative for Psychogeographic Studies (www. pipsworks.com); Stalker (http:/ / www.osservatorionomade.net/); Toronto Psychogeography Society (http://www.psychogeography.ca/); Virtual Psychogeographical Association (http:/ / psychogeography.org.uk/index.php); Wilfried Hou Je Bek (www. socialfiction.org)
Public Space - The Commons: A space or set of resources open to public use.

Basic resources, such as air and water, have often been thought of as a commons. However, exactly what constitutes a "commons" has been undergoing changes, particularly in the last twenty-five years. Much (if not most) of the urban landscape has become privatized, commodified, increasingly regulated, and plastered with advertisements. The spaces where "the public" congregates are often privately owned and maintained, for example malls, coffee shops, and bookstores. This is not inherently good or bad, but it does present a new set of affordances and limitations that present a rich field of investigation for artists interested in how our "public" spaces are changing and just what the implications of this might be.

Canadian artist Cheryl L'Hirondelle recently presented a project about the ownership of air called awa ka-amaciwet piwapisko waciya / climbing the iron mountain (2004) at the $7 a^{*} 11 d$ International Performance Art Festival in Toronto, Canada. The project involved infiltrating parking garages, scaling the center of the stairwell in bare feet, and carrying pirate radio broadcasting equipment to the roof. As she climbed, L'Hirondelle would leave a chalk tag of Cree syllabics on the building which, when translated, means "I do this for the birds-it is still their domain." Upon reaching the roof, L'Hirondelle set up the pirate radio system and broadcast a half-hour program of Cree music, words from the audience who watched the performance, and her own songs [see Figure 12].

L'Hirondelle's project responds to the zoning and claiming of a space that was previously thought of (and, in some cultures, is still thought of) as a commons: the air above our heads. Reclaiming that space as a commons, however temporarily, is a strategic gesture that contests the economics of ownership.

In a similar vein, Alex Villar (see Experiments) stages Temporary Occupations (2004) of private spaces that border on public spaces. The video shows a series of clips of the artist gracefully jumping fences and slipping behind boundaries of private areas that are adjacent to the New York sidewalks. He slips inside and outside of the private space, proceeding without pause on his way somewhere else. Using his body, Villar articulates the continuity (their shared "space-ness") between these private and public spaces and calls into question the purpose of these lines of demarcation.

The Institute for Infinitely Small Things researches corporate messages in public space by collecting Corporate Commands (2005) in an online database (see Data Collection). According to the Institute, a 


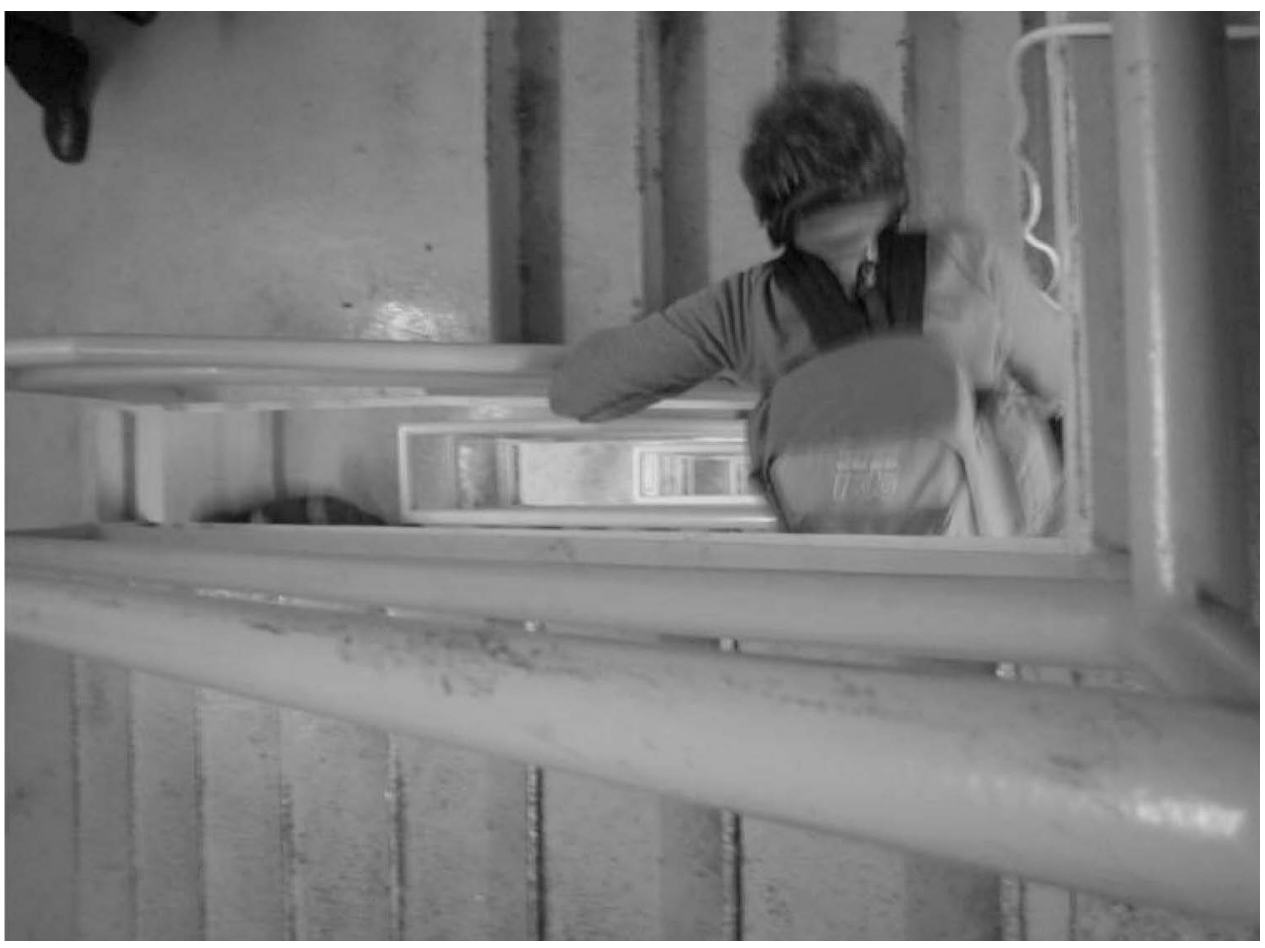

Figure 12. awa-ka-amaciwet piwapisko waciya/climbing the iron mountain (2004) by Cheryl L'Hirondelle. The artist scales a parking garage stairwell in her bare feet with a pirate radio rig in tow.

the sidewalk in Central

Square, a busy commercial district in Cambridge, MA. When pedestrians approached, the group would yell "Rollover!" and make way for the person by rolling over [see Figure 13].

The point of "Rollover" was not to convince people in Central Square not to use Cingular Wireless, nor to do something wacky or "crazy" to make people look at us as artists. In "Rollover", as with all the corporate commands, we were interested in posing the questions, "What happens when one takes Cingular seriously and rolls over right here? What will change in this environment? What will this action produce?" By treating each command as a map (as instructions for use) and by using commands developed in the private

corporate command is a slogan in the imperative that instructs the viewer to do something. These run the gamut from the familiar-“"Just do it!" (Nike), "Think Different" (Apple)— to the strange- "Surrender to smooth and creamy galaxy" (Galaxy Candy Bar), "Try being more of a woman" (Coty perfume). The Institute asserts that these commands not only play a significant role as a social force (shaping attitudes and behavior) but that they are also worthy of a more in-depth investigation through performance. So how does one begin to explore the influence of corporate messaging in public space? By treating each corporate command as a map (a recipe) to guide a concrete experimentation with the surrounding geography.

We are all inundated by advertising messages (3000 per day is the oft-cited figure), though most of us claim to ignore them. What happens when we stop ignoring them and start using them to test the environment around us? What happens when we attempt to enact what these commands are telling us to do? As an extension of the online collection, the Institute researches certain corporate commands more thoroughly by staging a performance of the command in the location where it occurs in public space. Donning white lab coats for these performances, some of the researchers perform the command while others take field notes, shoot digital photos or interview passersby. For example, on February 26th, 2005, the Institute performed "Rollover" (Cingular Wireless). Five researchers lay down underneath the "Rollover" poster and blocked sector to stage public activities, the Institute effects a reconsideration of and dialogue around the corporate presence in public space.

Related Terms: Experiments, Urbanism, Data Collection

Related URLS: Cheryl L'Hirondelle (www.ndnnrkey. net);

Alex Villar (www.de-tour.org); The Institute for Infinitely Small Things (www.infinitelysmallthings.net); Corporate Commands (www.corporatecommands. com)

\section{Scale: Experimentation with orders of magnitude.}

As the sciences have begun to measure the world in light-years and nanometers, we have seen a parallel increase in artistic investigations of the assumptions and implications of scale. Scale is often leveraged strategically by artists to effect a reconsideration of "the human"; particularly the narrow scale of the human. Affecting a shift in scale has the consequences of multiplying truths and complexifying perspectives. What is invisible at the human scale is revealed at the nanoscale. It's no longer so easy to believe that the aerial view map is the only way to describe our geography.

As part of spurse's project on urbanism (See Urbanism) for the exhibition "The Interventionists: Art in the Social Sphere" at the Massachusetts Museum of Con- 

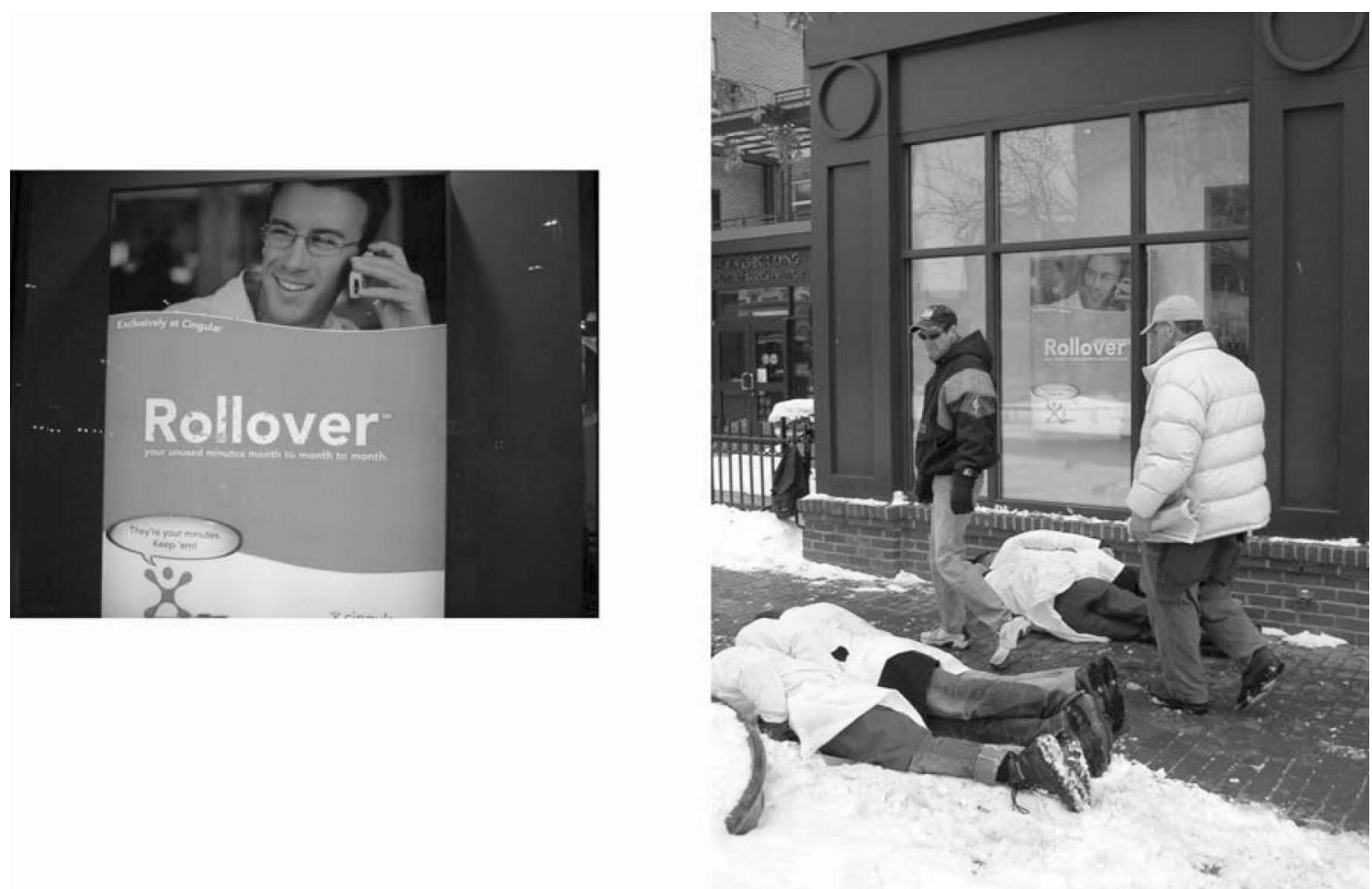

Figure 13. "Rollover", research performance by the Institute for Infinitely Small Things (2005).

temporary Art in 2004, artist Brian DeRosia conducted an experiment into the relative distances between the cities of Portland, ME (where he lives), North Adams, MA (the location of the museum), and Mexico City, Mexico (the most populous city in North America). These took the form of two books [see Figure 14], each containing a single line that travels across the pages which maps the distance between the cities, in miles, at a scale of 1 inch $=1$ mile. Though the North AdamsMexico City book has more pages than the PortlandNorth Adams book, you can still hold it in your hand and flip through the pages. In global conditions of urbanism and free market exchange, perhaps the semirural North Adams is not as far away from the megalopolis Mexico City as we might think.

At the Institute for Infinitely Small Things, we leverage scale strategically and semantically in order to provoke participants to think on a different scale. As part of the project, The Analysis of Infinitely Small Things (2004), we invited members of the public to go on expeditions to find infinitely small things at a particular site. This exercise is primarily about the production of a question about scale itself- "What is an infinitely small thing?"-which we hear repeatedly during each expedition.

Transformations of scale can happen in the reverse as well, when something small becomes human-size or larger. Artist Sharilyn Neidhardt organizes Human-Scale Chess Games, projects in which participants use the grid of the city as a giant chess board. Two experts play chess in a central location and their board is transposed on city streets (see Urbanism). People dressed as chess pieces stand on street corners until they receive directions to move via a cell phone.

Other groups have experimented with explicit juxtapositions and equivalencies of scale. For the exhibition 1:100 (2004) at the DCKT Contemporary Gallery in Chelsea, NYC, Glowlab enlarged the gallery floor plan and placed it over the a map of the surrounding neighborhood at a scale of 1:100 ( 1 foot in the gallery $=$ 100 feet in the neighborhood) [see Figure 15]. Invited artists were requested to respond to their location in the gallery/neighborhood by creating new projects both inside and outside the gallery space. The artist Shih-Chieh Huang, for example, created a sculptural installation of plastic containers, relay circuits, and microcontrollers, all found or purchased at dollar stores, pet shops and hardware stores in the neighborhood. Street artist Swoon inserted peep-holes throughout the neighborhood's street signs, through which one sees fictitious scenes of urban life. These miniature images are then reproduced as large-scale three-dimensional works in the gallery. By linking these two scales-interior and exterior space-in a relationship of equivalency, Glowlab affects a sort of cognitive imperative to consider the outside from the position of the inside. When in the gallery, one is always wondering what the relationship of the materials is to the neighbor- 


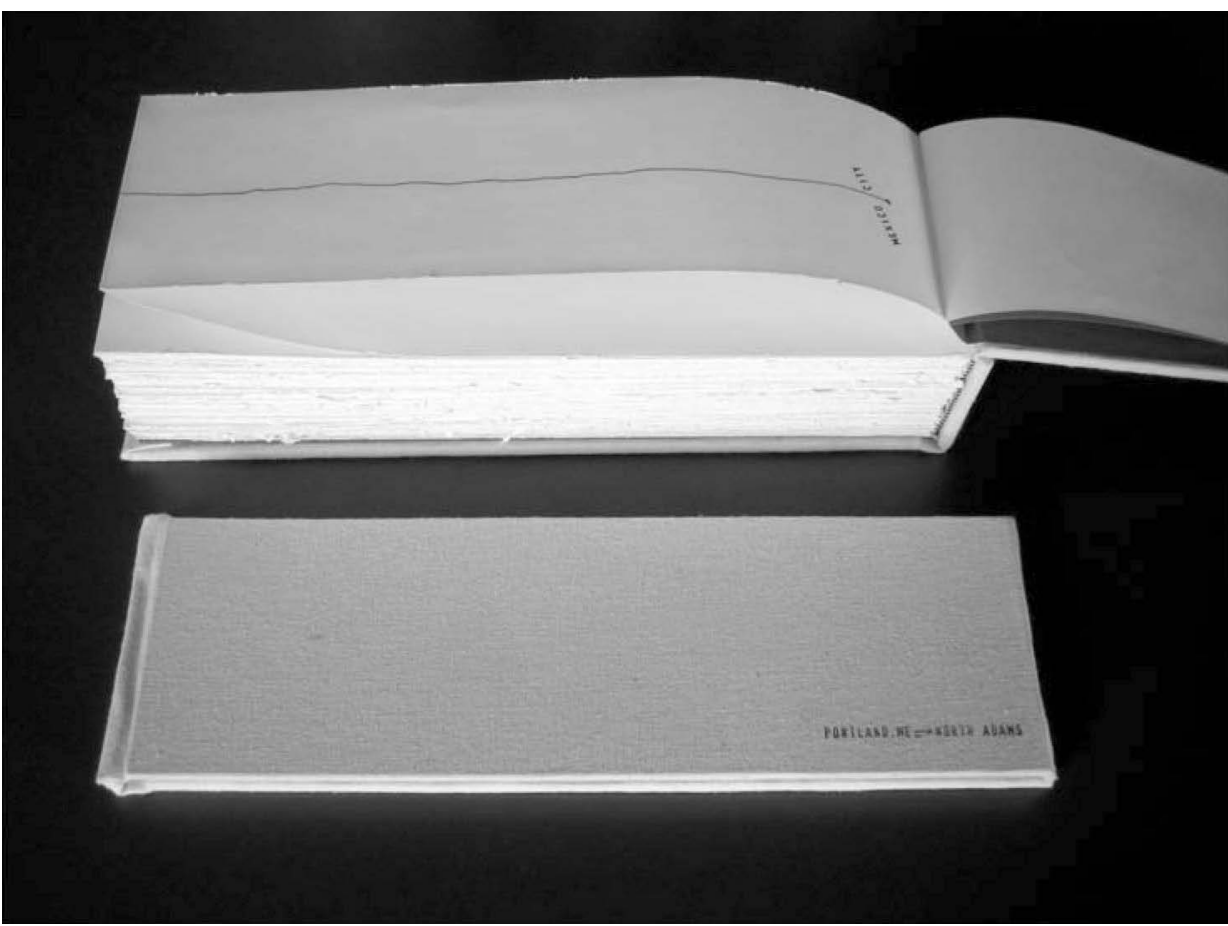

Figure 14. Portland-North Adams, North Adams-Mexico City, 1 inch=1 mile (2004), by Brian DeRosia. hood, what performances led these objects here, and whether something related to the inside might be hidden in the surrounding space.

Related Terms: Complexity, Public Space - The Commons, Urbanism

Related URLS: 1:100 Exhibit (glowlab.blogs.com/1_100/); The Institute for Infinitely Small Things (www.infinitelysmallthings.net)

Transdisciplinary: Working and studying simultaneously in/ with/through multiple disciplines and, additionally, always paying attention to what falls outside of their scope and what they do not include.

Artists have always borrowed from other fields of study and activity. Perhaps it is only the pace that has accelerated-new and strange disciplinary combinations seem to arise every day. For example, spurse's Mapping the Working Coasts of Maine (see Mobility), utilizes techniques from statistical psychology, ethnography, performance art, and maritime studies to conduct its psychogeographic research into the changing landscape of the coasts.

The Institute for Applied Autonomy is one of the rare organizations in which the work has not only borrowed techniques from disciplines such as software engineering, robotics, performance art, and political activism to create a transdisciplinary space, but is also contributing to an ongoing dialogue within the disciplines of design \& engineering. The Institute for Applied Autonomy writes software to "extend the autonomy of human activists" and tests it in commercial and political situations (see Political). The Institute also gives presentations and publishes research about this work in the design and engineering communities, allowing the work "outside" the disciplines to flow back "inside" and contribute to shaping and changing the borders of these disciplines themselves.

Related Terms: Mobility, Political

Related URLS: The Institute for Applied Autonomy (www.appliedautonomy.com) 


\section{Urbanism: The condition of living in a city.}

Over half the population of the world currently lives in an urban context. Because of this, the collective spurse makes the claim that "we have crossed a threshold and entered into a global condition of a new and radically urban geography" (Thompson, 2004). Central to spurse's claim is that, in a world of explosive urbanism, it is no longer tenable to think of urban vs. suburban, city vs. country, human vs. nature, as if these categories were for things that were separate from each other. What is urban is increasingly and inextricably a factor in everyone's lives, whether they live in a penthouse or on a farm. Especially in the world of the Internet and massively distributed systems of manufacturing and production, how can we begin to reconceptualize where one city begins and the other ends?

To explore these questions, spurse developed a research institute at the Massachusetts Museum of Contemporary Art devoted to the investigation of the conditions of urbanism, particularly as they relate to Mexico City (where a number of spurse members live) and North Adams, Massachusetts, (the small, rural town where MassMoCA is situated). Called sans terre: a temporary institution for the investigation of urbanism (2004), the institute is composed of documentation from walks between and around Mexico City and North Adams, over 100 different maps, psychogeographic diagrams, physical material samples, interviews and a host of other materials [see Figure 16]. The exhibit is laid out in a three-dimensional map that traces spurse's route from Mexico City to North Adams. The group has a call for researchers posted at the installation of this institute/exhibition that invites people to come and use the institute's archives (see Data Collection) for their own investigations.

Artists Anna María Bogadóttir and Malene Rørdam investigate this question playfully in their project $\mathrm{New}$ Copen York Hagen (2004). The two Danish artists superimposed a map of Copenhagen on New York City and proceeded to lead a tour of Copenhagen through the streets of Manhattan. Participants are handed postcards of famous tourist attractions in Copenhagen and encouraged to describe their impressions and send the postcard "home".

In these projects, geographical space is increasingly malleable and flexible, subject to overlays, transformations, and transpositions. Hybridizing physical space (e.g. by cross-breeding two or more cities) serves to call attention to the condition of urbanism, what other cities and spaces are implicated in the urban, and who participates in the urban. These projects invent new spaces for experimentation with these questions.

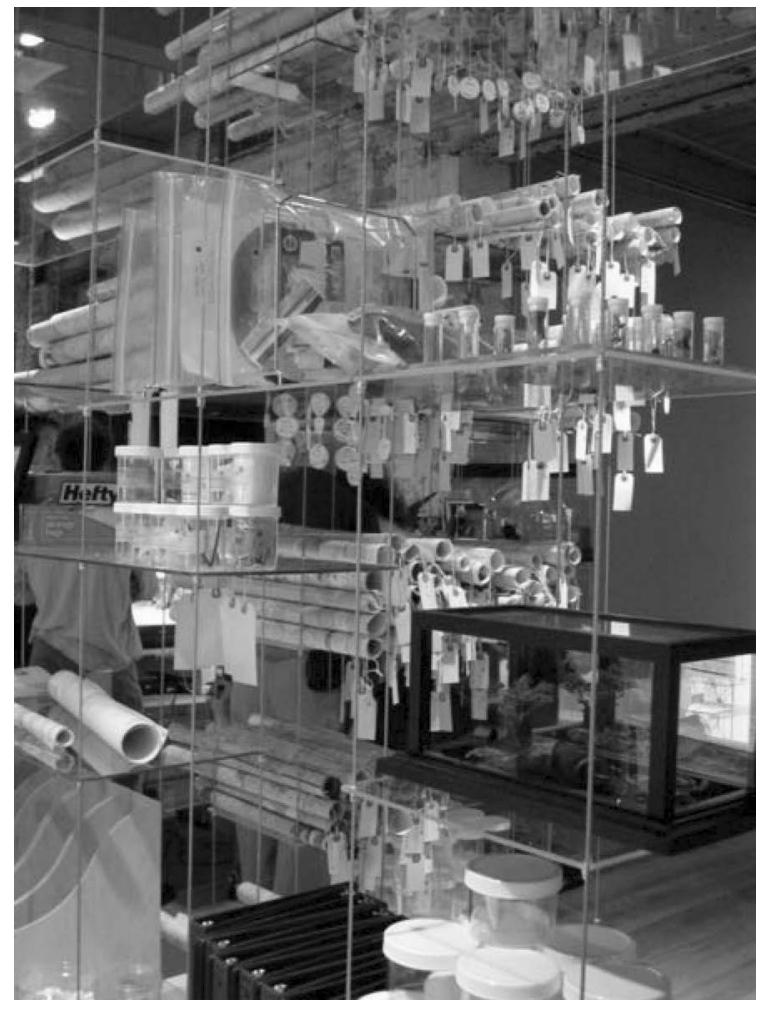

Figure 16.16 sans terre, a temporary institution for the investigation of urbanism (2004, by spurse.

Related Terms: Mobility

Related Urls: sans terre (http:/ / www.spurse.org/ sansterre.html);

New Copen York Hagen (http:/ /glowlab.blogs.com/ psygeocon/2004/02/participant_06.html)

\section{Where to Go From Here: an Ethics of Experimenta- tion}

Thinking of maps as recipes opens an array of possibilities for critical, political, social, and aesthetic experimental engagements with the world. Many of the projects discussed in the dictionary are exactly this: experiments in the production of space, the production of subjectivity or the production of power. Rather than knowing exactly where to go, what to produce and how to get there, these artists use maps and other technologies in order to go somewhere else. Note that it's not about going just "anywhere"; an ethics of experimentation is anything but arbitrary. What an ethics of experimentation proposes is the development of open systems that will produce emergent outcomes. All of these artists experiment with a particular territory in specific ways in order to reach unforeseen destinations. 


\section{REFERENCES}

Anon., 1958. Preliminary Problems in Constructing a Situation. Situationniste Internationale, No. 1.

Castells, M., 2000. The Rise of the Network Society. Malden, MA: Blackwell.

DeCerteau, M., 1984. The Practice of Everyday Life. Berkeley, CA: University of California Press.

Deleuze, G., 1988. Foucault. Minneapolis, MN: University of Minnesota Press.

Di Justo, P., 2004. Protests Powered by Cellphone. The New York Times, September 9.

Institute for Applied Autonomy, http:/ / www.appliedautonomy.com/mission.html

Rajchman, J., 2000. The Deleuze Connections. Cambridge, MA: MIT Press.

Rolnik, S., 1998. Sentimental Cartography. Translated from the Portuguese by A. Pedrosa and V. Cordeiro. http://www1.uol.com.br/bienal/24bienal/rot/ txt_ing_ensroln.htm. Extracted from Rolnik, S., 1989. Cartografia sentimental, transformaçaoes contemporéneas do desejo. Sâo Paulo: Editora Estaçâo Liberdade,15-16; 66-72.

Thompson, N., 2004. Sans Terre: A Temporary Institution for the Investigation Of Urbanism. http:/ / www.spurse. org/sansterre.html

U.S. Department of Housing and Urban Development. 1999. About the Empowerment Zone. http:/ / www.cityofboston.gov/bra/bostonez/about/about.asp 